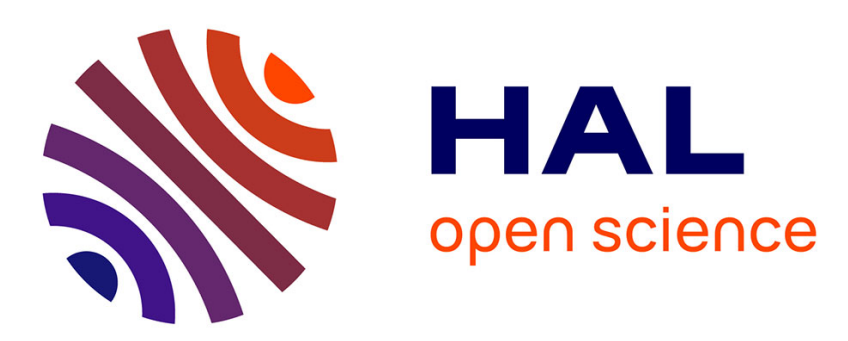

\title{
Fungal colonization of phyllosphere and litter of Quercus rotundifolia Lam. in a holm oak forest (High Atlas, Morocco)
}

\author{
Nassima Sadaka, Jean-François Ponge
}

\section{- To cite this version:}

Nassima Sadaka, Jean-François Ponge. Fungal colonization of phyllosphere and litter of Quercus rotundifolia Lam. in a holm oak forest (High Atlas, Morocco). Biology and Fertility of Soils, 2003, 39 (1), pp.30-36. 10.1007/s00374-003-0666-6 . hal-00498569

\section{HAL Id: hal-00498569 \\ https://hal.science/hal-00498569}

Submitted on 7 Jul 2010

HAL is a multi-disciplinary open access archive for the deposit and dissemination of scientific research documents, whether they are published or not. The documents may come from teaching and research institutions in France or abroad, or from public or private research centers.
L'archive ouverte pluridisciplinaire HAL, est destinée au dépôt et à la diffusion de documents scientifiques de niveau recherche, publiés ou non, émanant des établissements d'enseignement et de recherche français ou étrangers, des laboratoires publics ou privés. 


\section{FUNGAL COLONIZATION OF PHYLLOSPHERE AND LITTER OF QUERCUS ROTUNDIFOLIA LAM. IN A HOLM OAK FOREST (HIGH ATLAS, MOROCCO)}

Nassima SADAKA ${ }^{1}$ \& Jean-François PONGE ${ }^{2 *}$

${ }^{1}$ Université Cadi Ayyad, Faculté des Sciences Semlalia, Laboratoire d'Ecologie Terrestre, Boulevard Prince Moulay Abdellah, BP 2390, 40000 Marrakech, Morocco

${ }^{2}$ Muséum National d'Histoire Naturelle, CNRS UMR 8571, 4 avenue du Petit-Château, 91800 Brunoy, France

${ }^{*}$ Correspondence: J.F. Ponge

Fax: +33 160465009

E-mail: jean-francois.ponge@wanadoo.fr 
SUMMARY: The microfungal flora of holm oak living, senesced and litter leaves was studied at five different stages of decomposition using three different isolation methods. Holm oak leaves are first colonized on the tree by a variety of primary saprophytes such as Trichothecium, Aureobasidium, Cladosporium, Epicoccum and Alternaria. After leaf fall there is an intensive development of the fungal flora, including both species already present in the phyllosphere and new colonizers from the litter layer. With increasing decomposition initial colonizers gradually disappear, being replaced by other forms. When all isolation methods were pooled, maximum biodiversity (species richness) of the fungus flora was observed during the first three stages of leaf litter decomposition, but strong variation occurred according to the isolation method. Sterilization of the leaf material revealed that a number of fungal strains were present at the inside of holm oak leaves before abscission, increasing from living to senescent stage, and that a strong decrease in the internal colonization of leaf litter was observed at late decomposition stages.

Keywords: Decomposition, Fungal succession, Isolation methods, Biodiversity

\section{Introduction:}

Fungi play fundamental roles in leaf litter decomposition processes within forest ecosystems (Swift et al. 1979; Cooke and Rayner 1984). Fungal species distribution and successional changes occurring during the decomposition process have been extensively investigated on several litter types and using different isolation methods (Kendrick and Burges 1962; Struwe and Kjøller 1986; Rosenbrock et al. 1995). Mechanisms underlying fungal successions as well as advantages and biases of the different methods have been reviewed and discussed by Frankland $(1992,1998)$.

The decomposition of tree leaves is not entirely confined to the litter layer on the forest floor (Ruinen 1961; Davenport 1976). In fact, decay processes are initiated as soon as the leaf is formed, and the large surface of this plant organ is exposed to microbial and 
faunal attack during its entire life, senescence and death. Relatively few studies have been designed to follow the colonization of leaves from their initial expansion to their incorporation into humus (Ruscoe 1971; Wildman and Parkinson 1979; Mishra and Dickinson 1981).

Less is known about long-living evergreens leaves, though Ruinen (1961) demonstrated that persistent leaves of tropical plants supported complex and extensive microbial populations. The paucity of information concerning qualitative aspects of fungi inhabiting holm oak leaves in Mediterranean areas (Vardavakis 1988), and particularly in Morocco, prompted the investigation reported here. The present study examined the fungal colonization of holm oak leaves from phyllosphere (living and senescent leaves) to leaf litter at five different stages of decomposition.

\section{MATERIAL AND METHODS}

\section{Study Material}

Holm oak (Quercus rotundifolia Lam.) forms typical climax forests that are widely distributed throughout the western Mediterranean area (Maghreb, Central Spain), mostly in mountains where it tolerates a dry and cold climate (Achhal et al. 1980; Barbero and Loisel 1980). It is characterized by persistent, spiny, sclerophyllous foliage. Litter falls throughout the year, mainly from April to June (Lossaint and Rapp 1978). The thickness of litter is determined by seasonal litter fall, decomposition rate, and biennial cycles of large and small amounts of litter input (Rapp 1971; Poli et al. 1974; Sadaka-Laulan and Ponge 2000).

\section{Study area}

The investigation was performed in a holm oak forest dominated by Quercus rotundifolia Lam. (3-7 m height, 85-95\% cover), located at Toufliht on the northern slope of the High Atlas, Morocco. The climate is of the sub-humid to semi-arid Mediterranean type, with most precipitation from October to February and a long warm dry period from May to 
September (mean annual rainfall $840 \mathrm{~mm}$; maximum summer temperature $30.5^{\circ} \mathrm{C}$ and minimum winter temperature $1^{\circ} \mathrm{C}$ ).

\section{Sampling method}

Samples were collected in May 1999, at the time of optimum litter-fall. Leaves were collected directly on the phyllosphere and in several litter horizons from ten trees growing not far from each other within a one are area. Still attached leaves were separated into living (green) and senescent (yellow) leaves, irrespective of their age. The mean duration of life of holm oak leaves has been estimated to two years, but leaf fall may occur during the first as well as during the third year of life (Rapp 1969). Leaves from the litter layer were divided into five stages of decomposition (Sadaka-Laulan and Ponge 2000) according to morphological criteria such as colour, thickness and hardness (Table 1). After pooling and throroughly mixing the samples per category, forty-eight leaves were randomly selected within each of the seven categories of phyllosphere and litter leaves.

\section{Fungal isolation}

A combination of isolation methods was applied in order to obtain more information about the composition of leaf fungal flora and to differentiate epiphytic from endophytic flora.

One leaf disk was punched from each collected leaf with a sterile cork borer $(6 \mathrm{~mm}$ in diameter), avoiding primary veins. Leaf disks obtained were subdivided into three parts, corresponding to the three techniques used: washing, surface-sterilization, moist chambers.

*Washed leaves: This method removes all easily detachable fungal propagules on the surface and isolates only mycelia growing actively on and in the leaf (Kendrick and Burges 1962; Macauley and Thrower 1966; Osono and Takeda 1999). Sixteen disks of each leaf type were serially washed in a sterile tube by mechanical shaking. First, the disks were washed during $5 \mathrm{~min}$ in two changes of sterile distilled water containing one drop of Tween 80, a wetting agent, then rinsed eight times with sterile distilled water ( 2 min per 
washing). After blotting them on sterile filter paper, leaf disks were plated out on $2 \%$ Malt Extract Agar (MEA) added with Chloramphenicol, an antibacterial agent. This medium isolates a large spectrum of fungal strains and also allows rapid fungal growth (Wildman and Parkinson 1979).

For each leaf type, four Petri dishes were plated with four disks each. Since each disk was taken from a single leaf, we can consider that we have 16 replicates in total, taking into account that variation between individual leaves was more important than variation between Petri dishes.

After $48 \mathrm{~h}$ of incubation at $23^{\circ} \mathrm{C}$ in darkness, the plates were observed daily during 10 days, until no new colonies appeared. As soon as they were observed, fungal colonies were transferred to fresh MEA plates for isolation. The identification was done at the genus level using Barron (1968), Arx (1974) and Carmichael et al. (1980), then at the species level using many specialized monographs.

*Surface sterilized leaves: designed to isolate internal fungi (Wildman and Parkinson 1979; Espinosa-Garcia and Langenheim 1990). The leaf disks were surface sterilized for $60 \mathrm{sec}$ by immersion in $1 \%$ sterile $\mathrm{AgNO}_{3}$, followed by two 2-min washings in $1 \% \mathrm{NaCl}$ and five 2-min washings in sterile distilled water. Concerning stages IV and V, owing to their advanced decomposition, the duration of immersion in $\mathrm{AgNO}_{3}$ has been reduced to $30 \mathrm{sec}$. The disks were then treated as for washed leaves. Cultures were incubated for 2 weeks and examined regularly after the second or third day.

*Moist chambers incubation: used in an attempt to induce sporulation of fungi which might have been unable to compete with faster growers on nutrient media. Leaf disks were washed as for the first method and subsequently kept in sterile moist chambers (Keyworth 1951) for 30 days. This long period enables fungi originally present as propagules to sporulate (Lindsey 1976; Gourbière 1988).

The results were expressed in terms of numbers of isolates for each species from the 16 leaf disks treated by each method. Species were then ranked according to, first, their preferential stage and, second, their coefficient of variation (\%). The preferential 
stage was determined using the following formula: $\left(1 \cdot X_{1}+2 \cdot X_{2}+3 \cdot X_{3}+4 \cdot X_{4}+5 \cdot X_{5}+6 \cdot X_{6}+7 \cdot X_{7}\right)$ / $\left(X_{1}+X_{2}+X_{3}+X_{4}+X_{5}+X_{6}+X_{7}\right)$ where numbers 1 to 7 correspond to the rank attributed to the leaf stage, 1 for living, 2 for senescent, until 7 for stage $V$. $X_{1}$ to $X_{7}$ correspond to the total number of isolates for each species at each stage using the three isolation methods. It should be noted that this calculation method allowed to determine the mean stage at which a given fungal strain could be found, not necessarily its preferential stage, which should be the mode of the distribution.

\section{Data analysis}

Frequency data (numbers of isolates of each fungal species at each leaf stage using each of the three isolation methods) were subjected to correspondence analysis, a multivariate method using the chi-square distance between individuals and between variables in a symmetrical manner (Greenacre 1984). The different fungal species were the active variables. Leaf stages (living leaves, senescent leaves, stages I, II, III, IV and V), and isolation methods (washing, surface sterilization and moist chambers) were treated as passive variables, i.e. they were projected on the factorial axes as if they had been involved in the analysis, without contributing to the factorial axes. They were coded as 1 or 0 . In order to give the same weight to all variables (active and passive) they were transformed to mean 20 and unit variance by $X=(x-m) / s+20$, where $x$ is the original value, $m$ is the mean of a given variable and $s$ is its standard deviation (Ponge and Delhaye 1995). The addition to each standardized variable of a constant 20 made all values positive, because correspondence analysis deals only with positive numbers, commonly counts (Greenacre 1984). Following this transformation, factorial coordinates of variables can be interpreted directly in terms of their contribution to the factorial axes. The further a variable is projected from the origin of the axes (barycentre) along a factorial axis, the more it contributes to this axis. 


\section{RESULTS}

Table 2 lists the 36 fungal species and their frequencies recorded by stage and isolation method. Results revealed successional changes in the fungal flora of phyllosphere and litter. Figure 1 shows an increase in species richness from living to freshly fallen leaves (stage I), followed by a decrease until stage $\mathrm{V}$, the most decomposed litter, just before incorporation into humus. The mean number of fungal colonies (total numbers for 16 disks, averaged among the three isolation methods) shows the same bell-shaped curve, but with a slight decrease from green to moribund leaves while the maximum extended to the first three stages of decomposition.

The phyllosphere microflora consisted of relatively few species (13 among 36). Trichothecium roseum and Ulocladium chartarum exhibited a high levels of detection on green leaves. Aureobasidium pullulans, Cladosporium cladosporioides, Alternaria alternata and Epicoccum purpurascens were found on living as well as on senecent leaves, with maximal frequencies of isolation on senescent leaves. Species from the latter group were also recorded in most litter stages, except the final one (stage $\mathrm{V}$ ). The appearance of Acremonium sp, Fusarium oxysporum and white sterile mycelium coincided with senescence.

Twenty-three species were recorded only on litter. There was a progressive change in the fungus flora of holm oak leaves during decomposition. Some species appeared as soon as leaf fall (Marasmius quercophilus, Trichoderma koningii, sterile mycelia) while others were late colonizers (Aspergillus glaucus, Penicillium chrysogenum, Phialophora sp.). Phyllosphere inhabitants such as C. cladosporioides and A. pullulans were also isolated frequently from freshly fallen litter and tended to decrease progressively until stage IV, whereas species of Mucor and Trichoderma were rarely found at an early stage of decomposition. From older litter stages high colonization rates were registered for the genera Trichoderma, Mucor, Penicillium and Aspergillus. Some species were isolated only from one (Trichoderma pseudokoningii) or two stages (Basidiomycetes S41 and S42, green sterile mycelium, Stachybotrys atra). 
Serial washing, surface-sterilization and moist chambers yielded $42 \%, 15 \%$ and $43 \%$ of total colonies, respectively (Table 2 ). The low number of records from surfacesterilized leaves may indicate that relatively few species were able to penetrate internal tissues. The three methods combined revealed that $27 \%$ of the total fungal flora came from the phyllosphere and $73 \%$ came from the litter. The omnipresent $C$. cladosporioides and $A$. pullulans and other species such as Trichothecium roseum, Ulocladium chartarum and Alternaria alternata were isolated by all methods. Most species, and particularly fastspreading micromycetes such as Trichoderma, Mucor and Penicillium have been detected simultaneously by washing and moist chambers. Marasmius quercophilus was observed only in moist chambers while Acremonium sp., Alternaria tenuissima, Ulocladium atrum and Epicoccum purpurascens were never recorded by this method. Few internal colonists have been isolated by surface-sterilization only, such as Chaetomium globosum, Basidiomycetes S41 and S42, hyaline and dark sterile mycelia.

All isolation methods established that fungal diversity increased with senescence and after leaf-fall (Fig. 2). As the decomposition of oak litter proceeded, species richness decreased progressively while the mean isolation frequency varied only little before stage V. During later stages (IV and V) few species have been isolated by surface sterilization, which could however indicate that the leaf inside was affected by sterilization in spite of our effort to reduce the time of immersion.

When considering coefficients of variation of isolation frequencies, some species appeared to be restricted to some particular stages, while others exhibited a large spectrum of occurrence (Table 2). For instance, $T$. roseum was nearly restricted to living leaves $(\mathrm{C} . \mathrm{V} .=232 \%)$ while $U$. chartarum, B. cinerea and $A$. alternata seemed to prefer senescent leaves but were also found in other stages $(149,135 \%$ and $113 \%$, respectively). Trichoderma pseudokoningii was isolated only at stage III and exhibited the highest coefficient of variation (265\%). It should be noted that all species preferring stage V (A. glaucus, $P$. chrysogenum and Phialophora $s p$.) occurred only at this stage (C.V.=265\%). 
Axes 1 and 2 of correspondence analysis extracted $19.6 \%$ and $16.2 \%$ of the total variance, respectively. Fungal species (active variables), leaf stages and isolation methods (passive variables) were projected in the plane of the first two factorial axes (Fig. 3). Correspondence analysis showed that phyllosphere and stage I species were mostly detected by washing and to a lesser extent by surface-sterilization while litter species, and more particularly stages III to V, were mostly detected by moist chambers. Other results concerned the classification of fungal species along a gradient of increasing ageing of leaves, from positive values of Axis 1 (right side of the graph) to negative values (left side of the graph). Stages were spread along Axis 1 in the same order as they were stratified in the ecosystem, except senescent leaves, which were projected somewhat farther from the origin than living leaves. Axis 2 opposed washing to sterilization methods, highlighting advantages of one or the other method for the different fungal strains. For instance, sterilization revealed sterile basidiomycetes (S41 and S42), green and brown sterile mycelia and Chaetomium globosum, while washing revealed all Trichoderma species and many other highly-sporulating micromycetes.

\section{DISCUSSION}

The phyllosphere harboured relatively few fungal species such as Trichothecium roseum, Aureobasidium pullulans, Cladosporium cladosporioides, Alternaria alternata, Ulocladium chartarum, Botrytis cinerea and Epicoccum purpurascens. These fungi have been detected by all methods and are grouped into the common primary saprophytes (Hudson 1968), except Botrytis cinerea, a plant pathogen (Smith 1969; Dickinson 1976), which has been isolated only by moist chambers in green and senescent leaves, and by washing only in senescent and stage I leaves. Isolation methods showed that these fungi were both superficial growers and internal colonists of green and senescent leaves. Hudson (1968) considered them to be present on living leaves as spores which become vegetatively active only at leaf senescence. However, the present investigation and others 
(Ruscoe 1971; Lindsey and Pugh 1976; Dickinson 1976; Wildman and Parkinson 1979) have shown that these fungi are active prior to leaf senescence.

As a whole, senescence is accompanied by a slight increase in species richness (Table 2, Fig. 2), but also by an increase in the internal colonisation of leaves, as depicted by higher colonial records after surface sterilization. However, among the fungi reported as endophytes by several authors, a number of taxa known to be frequent epiphytes are able to live endophytically within plant tissues (Petrini 1991). For instance, A. alternata and C. cladosporioides are phyllosphere colonizers able to penetrate into leaving leaf tissues at the onset of the senescence process. Epicoccum purpurascens may behave in a similar way. The senescence process apparently modifies the ecological niche provided by leaf tissues to "true" endophytes and allows the development of organisms that are usually better adapted to saprotrophic life (Petrini 1991).

The small range of fungi growing on phyllosphere indicates a rather extreme environment, probably due to the exposure to changing weather conditions, limited availability of nutrients, and the presence of antimicrobial compounds (O'Donnell and Dickinson 1980; Petrini 1991). Some primary saprophytes such as Cladosporium, Alternaria and Epicoccum are able to survive on leaf surfaces exposed to ultra-violet radiation and dryness by forming dark, thick-walled clamydospores and microsclerotia (Pugh and Buckley 1971, Dickinson 1981).

All species of the phyllosphere, except Trichothecium roseum, persisted in fallen litter and tended to disappear in oldest stages of decomposition (stages IV and V). Freshly fallen leaves (stage I) were invaded by several new colonists, which increased dramatically the species richness (Table 2, Fig. 1). Among new colonizers appeared Marasmius quercophilus and species of Trichoderma, Mucor, Penicillium and Aspergillus, which are considered as secondary saprophytes (Hudson 1968).

This study showed many similarities with results obtained by workers having studied very different leaf materials, highlighting that the successional process we observed seems to be universal, occurring in deciduous as well as evergreen leaves. 
However, the time needed for leaves to fall on the ground allows some fungus genera to develop in internal tissues a long time before leaf abscission. Everything happens as if the first stage of decomposition occurred on the tree, although with a restricted array of fungal strains.

Members of the genus Trichoderma are known to be secondary colonizers of a wide variety of forest litters and have been mostly recorded in relatively well decomposed materials (Domsch et al. 1980), but species differed in their affinity for temperature and moisture (Widden and Hsu 1987), which may explain why our six Trichoderma species were found at so different stages. Trichoderma species are also known for their ability to produce cellulases (Danielson and Davey 1973), thus they could play a role in the loss of weight of holm oak litter (Sadaka-Laulan and Ponge 2000), together with actively decomposing basidiomycetes such as Marasmius spp., as this has been shown to occur on inoculated Scots pine needles by Cox et al. (2001).

Physical and chemical characteristics of the leaf surface play an important role in governing the success or failure of fungal growth on, and subsequently in, the leaf. Hardness and thickness may be significant in the resistance of leaves to fungal penetration (Allen et al. 1991), which could explain the lower number of isolates obtained after surface sterilization (Fig. 2).

In a previous study (Sadaka-Laulan and Ponge 2000) we used the weight per unit area in order to follow the senescence and decomposition of holm oak leaves. We showed that leaves exhibited an increase in weight during senescence then stage I, followed by a decrease until stage $V$. A similar trend has been found here for the mycoflora and a significant correlation was obtained between leaf areal weight and total fungal isolates $(r=0.793, P=0.017)$. This allows us to hypothesize that the habitat size (here expressed by the areal weight) is an important determinant of the fungal population size, which can be explained by synergistic effects of space and nutrient availability (Kinkel 1991). 


\section{REFERENCES}

Achhal A, Akabli O, Barbero M, Benabid A, M'hirit A, Peyre C, Quezel P, Rivas-Martinez S (1980) A propos de la valeur bioclimatique et dynamique de quelques essences forestières au Maroc. Ecol Medit 5: 211-248

Allen EA, Hoch HC, Steadman JR, Stavely RJ (1991) Influence of leaf surface features on spore deposition and the epiphytic growth of phytopathogenic fungi. In: Andrews $\mathrm{JH}$, Hirano SS (eds) Microbial ecology of leaves. Springer-Verlag, New York, pp $87-110$

Arx JA von (1974) The genera of fungi sporulating in pure culture. Cramer, Vaduz

Barbero M, Loisel R (1980) Le chêne vert en région méditerranéenne. Rev For Fr 32: 531 543

Barron GL (1968) The genera of hyphomycetes from soil. Krieger, Huntington

Carmichael JW, Bryce Kendrick W, Conners IL, Sigler L (1980) Genera of hyphomycetes. The university of Alberta Press, Edmonton

Cooke RC, Rayner ADM (1984) Ecology of saprotrophic fungi. Longman, London

Cox P, Wilkinson SP, Anderson JM (2001) Effects of fungal inocula on the decomposition of lignin and structural polysaccharides in Pinus sylvestris litter. Biol Fertil Soils 33: 246-251

Danielson RM, Davey B (1973) The abundance of Trichoderma propagules and the distribution of species in forest soils. Soil Biol Biochem 5: 485-494 
Davenport RR (1976) Distribution of yeasts and yeast-like organisms on aerial surfaces of developing apples and grapes. In: Preece TF, Dikinson $\mathrm{CH}$ (eds) Microbiology of aerial plant surfaces. Academic Press, London New York, pp 325-360

Dickinson CH (1976) Fungi of the aerial surfaces of higher plants. In: Preece TF, Dikinson $\mathrm{CH}$ (eds) Microbiology of aerial plant surfaces. Academic Press, London New York, pp 293-323

Dickinson CH (1981) Biology of Alternaria alternata, Cladosporium cladosporioides and C. herbarum in respect of their activity on green plants. In: Blakeman JP (ed) Microbial ecology of the phylloplane. Academic Press, London New York, pp 169184

Domsch KH, Gams W, Anderson TH (1980) Compendium of soil fungi, vol. 1. Academic Press, New York

Espinosa-Garcia FJ, Langenheim JH (1990) The leaf fungal endophytic community of a coastal redwood population. Diversity and spatial patterns. New Phytologist 116: 89-98

Frankland JC (1992) Mechanisms in fungal succession. In: Carroll GC, Wicklow DT (eds) The fungal community, its organization and role in the ecosystem, $2^{\text {nd }}$ edition. Marcel Dekker, New York, pp 383-401

Frankland JC (1998) Fungal succession. Unravelling the unpredictable. Mycol Res 102: 115 
Gourbière F (1988) Structure spatio-temporelle de la mycoflore des premiers stades de décomposition des aiguilles d'Abies alba. Soil Biol Biochem 20: 453-458

Greenacre MJ (1984) Theory and applications of correspondence analysis, Academic Press, London

Kendrick WB, Burges A (1962) Biological aspects of the decay of Pinus sylvestris leaf litter. Nova Hedwigia 4: 313-342

Keyworth WG (1951) A Petri dish moist chamber. Trans Brit Mycol Soc 34: 291-292

Kinkel LL (1991) Fungal community dynamics. In: Andrews JH, Hirano SS (eds) Microbial ecology of leaves. Springer-Verlag, New York, pp 253-270

Lindsey BI (1976) A survey of methods in the study of microfungal succession on leaf surfaces. In: Preece TF, Dikinson CH (eds) Microbiology of aerial plant surfaces. Academic Press, London New York, pp 217-222

Lindsey BI, Pugh GJF (1976) Succession of microfungi on attached leaves of Hippophaë rhamnoides. Trans Brit Mycol Soc 6: 61-67

Lossaint P, Rapp M (1978) La forêt méditerranéenne de chênes verts. In: Lamotte M, Bourlière F (eds) Problèmes d'écologie, écosystèmes terrestres. Masson, Paris, pp $129-185$

Mishra RR, Dickinson CH (1981) Phylloplane and litter fungi of Ilex aquifolium. Trans Brit Mycol Soc 77: 329-337 
O'Donnell J, Dickinson CH (1980) Pathogenicity of Alternaria and Cladosporium isolates on Phaseolus. Trans Brit Mycol Soc 74: 335-342

Osono T, Takeda H (1999) Decomposing ability of interior and surface fungal colonizers of beech leaves with reference to lignin decomposition. Eur J Soil Biol 35: 51-56

Petrini O (1991) Fungal endophytes of tree leaves. In: Andrews JH, Hirano SS (eds) Microbial ecology of leaves. Springer-Verlag, New York, pp 179-197

Poli E, Leonardi S, Bella R (1974) Produzione di littiera nella lecceta del M. Minardo (Etna) nel periodo Settembre 1970-Giugnio 1974. Archivio Botanico e Biogeografico Italiano 50: 86-106

Ponge JF, Delhaye L (1995) The heterogeneity of humus profiles and earthworm communities in a virgin beech forest. Biol Fertil Soils 20: 24-32

Pugh GJF, Buckley NG (1971) The leaf surface as a substrate for colonization by fungi. In: Preece TF, Dickinson $\mathrm{CH}$ (eds) Ecology of leaf surface micro-organisms. Academic Press, London New York, pp 431-445

Rapp M (1969) Production de litière et apport au sol d'éléments minéraux dans deux écosystèmes méditerranéens: la forêt de Quercus ilex L. et la guarrigue de Quercus coccifera L. Oecol Plant 4: 377-410

Rapp M (1971) Cycle de la matière organique et des éléments minéraux dans quelques écosystèmes méditerranéens. In: Cycle de la matière organique et des éléments minéraux dans quelques écosystèmes méditerranéens. Dynamique saisonnière de deux sols en climat tempéré. CNRS, Paris, pp 28-184 
Rosenbrock P, Buscot F, Munch JC (1995) Fungal succession and changes in the fungal degradation potential during the initial stage of litter decomposition in a black alder forest [Alnus glutinosa (L.) Gaertn.]. Eur J Soil Biol 31: 1-11

Ruinen J (1961) The phyllosphere. I. An ecologically neglected milieu. Plant Soil 15: 81109

Ruscoe QW (1971) Mycoflora of living and dead leaves of Nothofagus truncata. Trans Brit Mycol Soc 56: 463-474

Sadaka-Laulan N, Ponge JF (2000) Comparative leaf decomposition within the holm oak complex. Eur J Soil Biol 36: 91-95

Smith G (1969) An introduction to industrial mycology, 6e edition. Arnold, London

Struwe S, Kjøller A (1986) Changes in population structure during decomposition. In: Jensen V, Kjøller A, Sørensen LH (eds) Microbial communities in soil. Elsevier, Amsterdam, pp 149-162

Swift MJ, Heal OW, Anderson JM (1979) Decomposition in terrestrial ecosystems, Blackwell, Oxford

Vardavakis E (1988) The mycoflora, production and decomposition of leaf litter in an Orno-Quercetum ilicis association. Pedobiologia 32: 167-176

Widden P, Hsu D (1987) Competition between Trichoderma species: effects of temperature and litter type. Soil Biol Biochem 19: 89-93 
Wildman HG, Parkinson D (1979) Microfungal succession on living leaves of Populus tremuloides. Can J Bot 57: 2800-2811 


\section{Figure legends}

Figure 1: Species richness and mean number of isolates of fungal colonies (averaged among the three isolation methods) \pm standard error.

Figure 2: Species richness and total frequency of isolation from phyllosphere and leaf litter by serial washing, surface sterilization and moist chambers.

Figure 3: Correspondence Analysis. Projection of active variables (fungal species) and passive variables (isolation methods, stages) in the plane of Axes 1 and 2. Codes of fungal species as in Table 2 . 
Table 1: Morphological features of the five decomposition stages of the holm oak leaf litter

$\overline{\text { Stage I Yellow, externally intact, thick, hard, lower side densely covered }}$ with green hairs

Stage II Yellow, slightly decayed but still thick and hard, hair cover on the lower side invaded by fungi

Stage III Brown, thin, soft, decayed, a few hairs still present

Stage IV Brown, thin, very soft, strongly decayed but still recognizable, no hair present

Stage V Bleached, very thin, brittle and more or less aggregated by fungal mycelium 
Table 2: Frequency of isolation of each fungal species (number of colonies developing on total 16 disks) from phyllosphere (living and senescent leaves) and leaf litter at five different stages of decomposition, by each isolation method.

$W=$ serial washing, $\mathbf{S}=$ surface sterilization, $M . C=$ moist chambers, Pref. $S t=$ preferential stage, $C . V .=$ coefficient of variation, $L L=$ living leaves and $\mathrm{SL}=$ senescent leaves.

\begin{tabular}{|c|c|c|c|c|c|c|c|c|c|c|c|c|c|c|c|c|c|c|c|c|c|c|c|c|}
\hline \multirow[b]{2}{*}{ Code } & \multirow{2}{*}{ 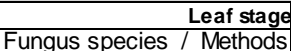 } & \multicolumn{2}{|c|}{ Living leaves } & \multicolumn{3}{|c|}{ Senescent lea } & \multicolumn{3}{|c|}{ Stage I } & \multicolumn{3}{|c|}{ Stage II } & \multicolumn{3}{|c|}{ Stage III } & \multicolumn{3}{|c|}{ Stage IV } & \multicolumn{3}{|c|}{ Stage $V$} & \multirow[t]{2}{*}{ Total } & \multicolumn{2}{|c|}{ Pref. St C.V.(\%) } \\
\hline & & $W$ & $\mathbf{S} \mid \mathrm{M} . \mathrm{C}$ & W & 0 & M.C & W & & M.C & W & & M.C & W & & M.C & W & & M.C & W & & M.C & & & \\
\hline Tr.r & Trichothecium roseum & 12 & 1315 & 2 & 3 & - & - & - & - & - &. & - & - & - & - & - & - & - & 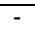 & - & - & 45 & LL & 232 \\
\hline Ul.c & Ulocladium chartarum & 2 & - & 2 & 1 & - & 4 & 1 & . & - & & & - & - & & - & - & & - & 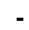 & & 18 & SL & 149 \\
\hline Bo.c & Botrytis cinerea & - & 8 & 3 & - & 6 & 4 & - & - & - & & 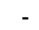 & - & - & - & - & 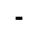 & - & - & - & - & 21 & SL & 135 \\
\hline Al.a & Alternaria alternata & 5 & - 13 & 9 & 3 & 9 & 5 & 2 & - & 3 & 1 & - & 2 & 1 & - & - & - & & - & - & & 53 & SL & 113 \\
\hline Ch.g & Chaetomium globosum & - & & - & - & - & - & 2 & - & - & 1 & & - & - & - & - & - & & - & - & & 3 & I & 184 \\
\hline$s . n$ & Aspergillus niger & - & - & - & - & - & 3 & - & - & 2 & . & - & - & - & 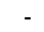 & - & - & & - & - & & 5 & I & 175 \\
\hline Gl.v & Gliocladium virens & - & - & - & - & - & 3 & - & - & 2 & . & & - & - & & - & 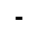 & & - & - & & 5 & I & 175 \\
\hline c.sp & Acremonium sp. & - & & 3 & 1 & - & 2 & 2 & - & - & . & - & - & - & - & - & 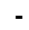 & 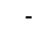 & - & 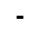 & & 8 & I & 171 \\
\hline Fu.o & Fusarium oxysporum & - & - & 2 & - & - & 2 & - & - & 3 & & - & - & - & - & - & - & & - & - & & 7 & I & 129 \\
\hline Al.t & Alternaria tenuissima & 2 & - & 3 & 3 & - & 3 & 4 & - & 2 & 1 & - & 1 & 1 & - & - & - & & - & - & & 20 & i & 96 \\
\hline Ul.a & Ulocladium atrum & 1 & - & 2 & 2 & - & 3 & 2 & - & 4 & 1 & - & 2 & 1 & - & - & 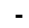 & - & - & - & - & 18 & I & 87 \\
\hline Ep.p & Epicoccum purpurascens & 5 & - & 9 & 2 & - & 3 & 2 & - & 2 & & - & 3 & - & - & 3 & 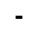 & 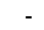 & - & - & & 29 & I & 84 \\
\hline Cl.c & Cladosporium cladosporioid & 7 & 3 & 10 & 3 & 10 & 5 & 2 & 11 & 4 & 1 & 8 & 3 & 3 & - & 2 & 2 & - & - & - & & 82 & i & 73 \\
\hline Au.p & Aureobasidium pullulans & 10 & 314 & 12 & 4 & 12 & 5 & 3 & 11 & 2 & 2 & - & 6 & 1 & 12 & 4 & - & 7 & - & - & - & 108 & i & 70 \\
\hline & ete (S42) & - & - & - & - & - & - & - & - & - & 3 & - & - & 1 & 15 & - & - & & - & - & & 4 & II & 198 \\
\hline Gr.St.M & Green sterile mycelium & - & & - & - & - & - & - & - & - & 2 & - & - & 1 & - & - & - & & - & - & & 3 & II & 184 \\
\hline Sta & Stach & - & - & - & - & - & 2 & - & - & 3 & . & - & - & - & - & - & - & - & - & - & & 5 & II & 175 \\
\hline St.M & lie mycelium & - & - & - & - & - & - & 8 & - & 2 & 6 & - & 1 & 11 & 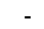 & 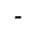 & 1 & & 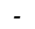 & 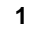 & & 30 & II & 115 \\
\hline Td.k & a koningii & - & & - & - & - & 4 & - & 13 & 4 & . & 7 & 7 & - & - & 6 & - & & - & 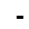 & & 41 & II & 111 \\
\hline & superba & 2 & - & 2 & - & - & 3 & - & - & 3 & . & & 7 & - & & - & - & & - & - & & 17 & II & 98 \\
\hline la.q & quercophilus & - & - & - & - & - & - & - & 12 & - & . & 14 & - & - & 11 & - & - & 10 & - & 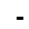 & & 47 & II & 95 \\
\hline Td.pk & Trichoderma pseudokoning & - & - & - & - & 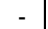 & - & - & - & - & . & - & 5 & - & - & - & - & - & - & - & & 5 & III & 265 \\
\hline 154 & Basidiomycete (S41) & - & - & - & - & - & - & - & 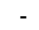 & - & 3 & - & - & 4 & - & 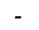 & 4 & - & 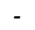 & - & & 11 & III & 127 \\
\hline Pe.s & pinulosum & - & - & - & - & - & 2 & - & - & 4 & & 8 & 2 & . & 7 & 2 & - & 5 & - & - & 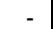 & 30 & III & 116 \\
\hline W.St.M & terile mycelium & - & - & - & 2 & - & - & 3 & - & 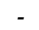 & . & & - & 2 & 9 & - & 1 & 7 & - & 3 & & 27 & III & 107 \\
\hline Td.v & Trichoderma viride & - & - & - & - & - & 1 & - & - & 1 & . & & 2 & - & & 1 & 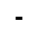 & & . & - & & 5 & III & 107 \\
\hline Td.sp & Trich & - & - & - & - & - & 1 & - & - & 8 & & - & 7 & - & - & 8 & - & - & 2 & - & & 26 & III & 102 \\
\hline Td.p & polysporum & - & - & - & - & - & 4 & - & - & 6 & . & 12 & 2 & - & 7 & 14 & - & 8 & - & - & & 62 & III & 96 \\
\hline Td.h & Trichoderma harzianum & - & - & - & - & - & - & - & 4 & - & . & 10 & - & - & 3 & - & - & & 11 & - & & 37 & III & 89 \\
\hline Mu.p & Mucor plumbeus & - & - & - & - & 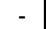 & 6 & 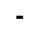 & - & 10 & & - & 5 & - & & 4 & ـ & - & 5 & & 7 & 3 & III & 87 \\
\hline Mu.h & Muco & - & - & - & - & - & 3 & - & 3 & 2 & 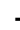 & 6 & 8 & - & 8 & 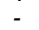 & - & 7 & - & - & & 46 & III & 84 \\
\hline Rh.s & Rhizopus stolonifer & - & - & - & - & 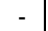 & 5 & - & - & 2 & . & 7 & 3 & - & 10 & 7 & - & - & - & - & 5 & 39 & III & 84 \\
\hline Pe.c & Penicillium citrinum & - & - & - & - & - & 2 & - & - & 1 & & & 1 & - & 6 & 2 & - & 7 & 2 & - & 11 & 32 & IV & 112 \\
\hline As.g & glaucus & - & - & - & - & - & - & 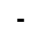 & - & 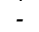 & & & & _. & & & 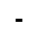 & & 3 & & & 8 & v & 265 \\
\hline Pe.ch & Penicillium chrysogenum & - & - & - & - & - & - & - & - & - & - & & - & - & - & - & - & - & 2 & 3 & - & 5 & V & 265 \\
\hline Ph.sp & Phialophora sp. & - & - & - & - & - & 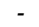 & - & - & - & - & - & - & - & - & - & - & - & 2 & - & - & 2 & V & 265 \\
\hline
\end{tabular}




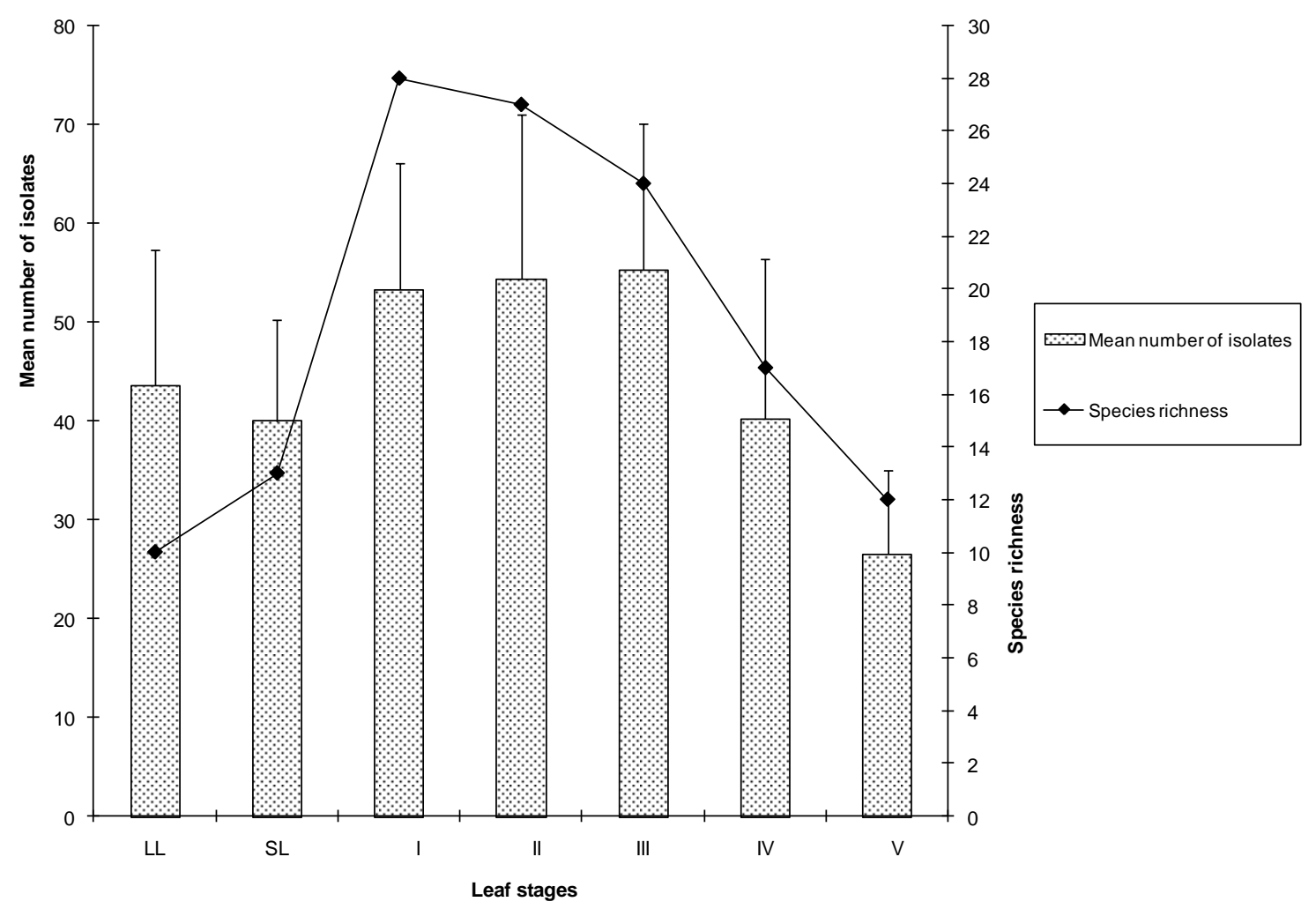

Fig. 1 

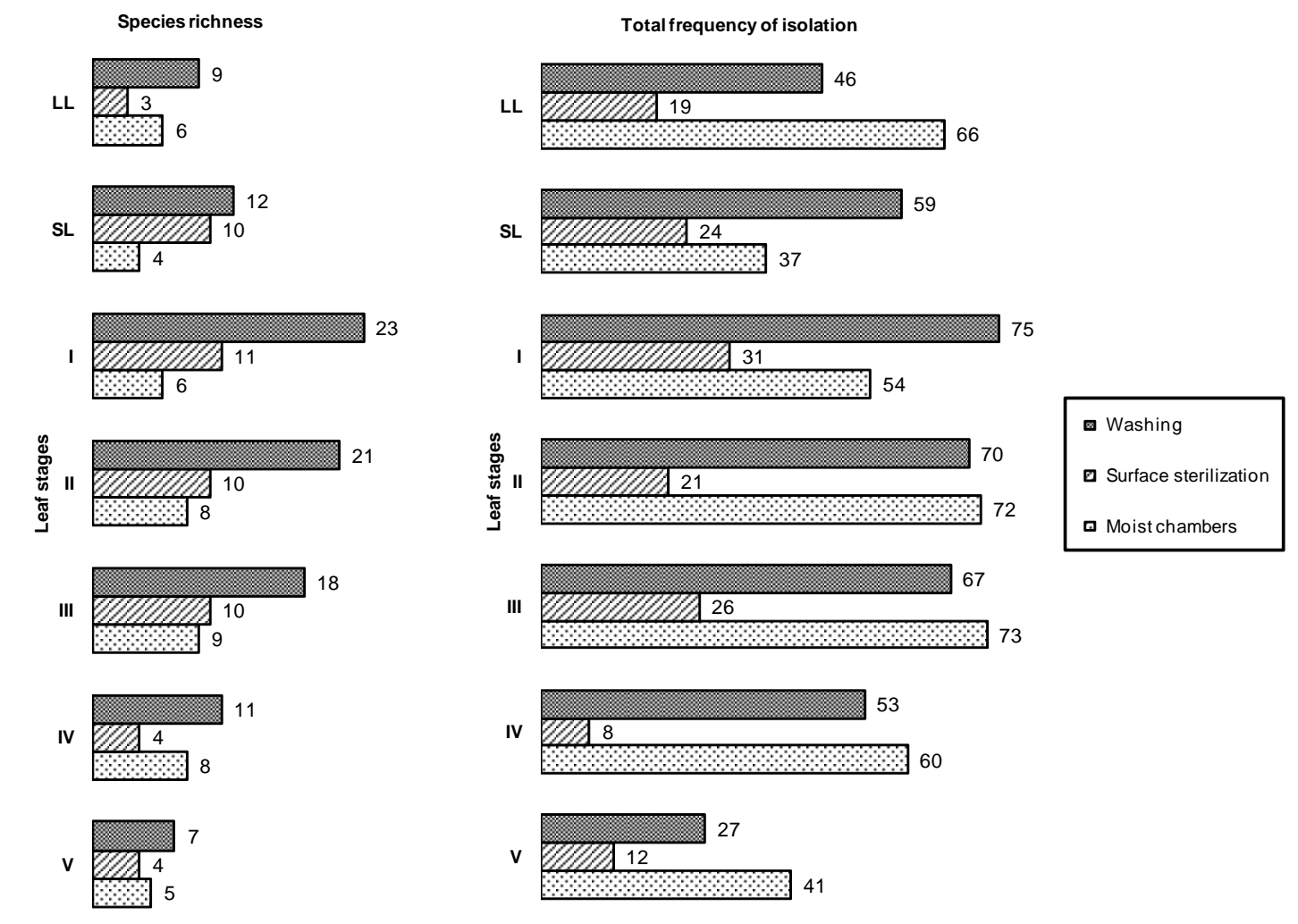

Fig. 2 


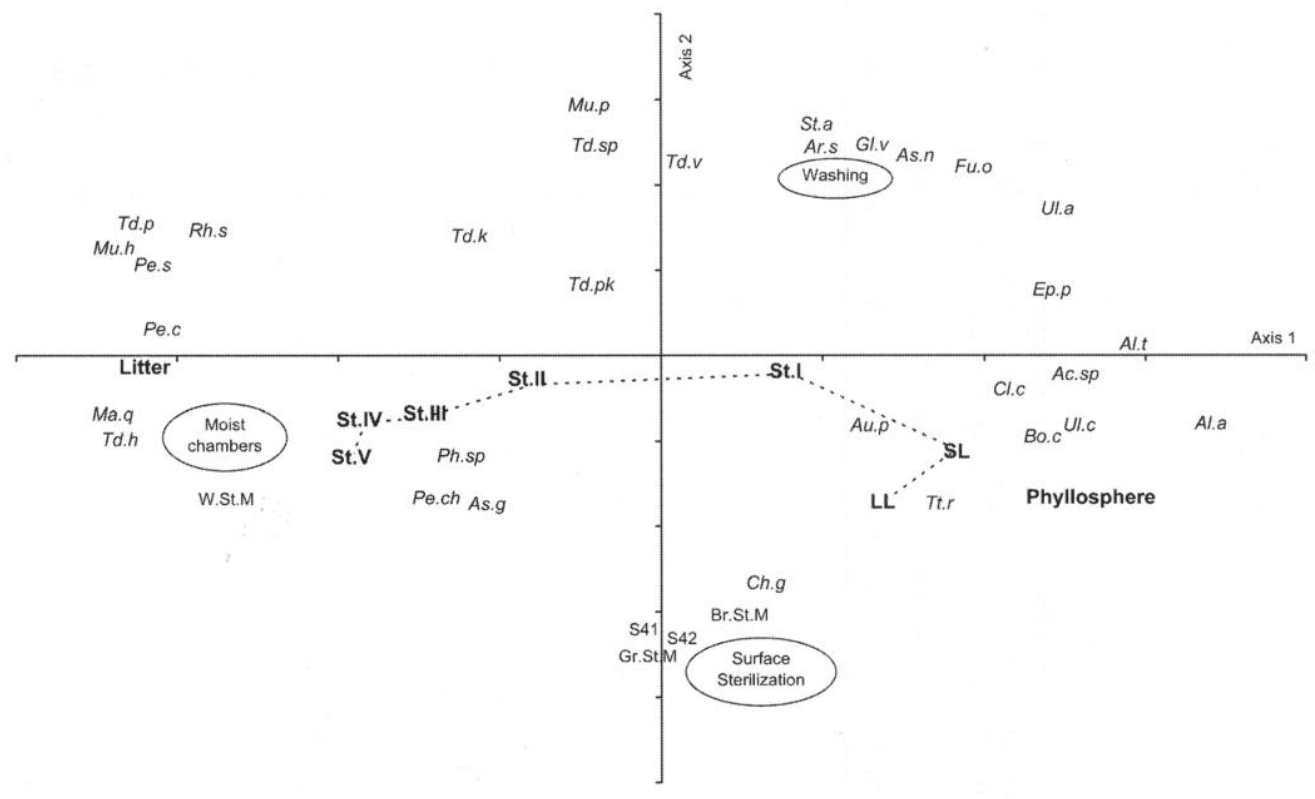

Fig. 3

23 